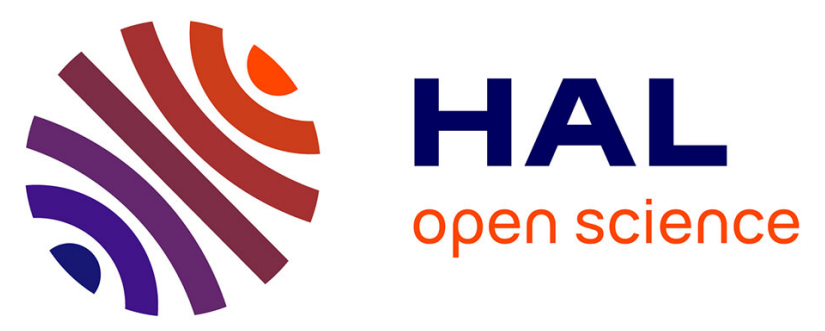

\title{
Scaled-up electrochemical reactor with a fixed bed three-dimensional cathode for electro-Fenton process: Application to the treatment of bisphenol A
}

Ayman Chmayssem, Samir Taha, Didier Hauchard

\section{- To cite this version:}

Ayman Chmayssem, Samir Taha, Didier Hauchard. Scaled-up electrochemical reactor with a fixed bed three-dimensional cathode for electro-Fenton process: Application to the treatment of bisphenol A. Electrochimica Acta, 2017, 225, pp.435-442. 10.1016/j.electacta.2016.12.183 . hal-01475803

HAL Id: hal-01475803

https://hal-univ-rennes1.archives-ouvertes.fr/hal-01475803

Submitted on 19 May 2017

HAL is a multi-disciplinary open access archive for the deposit and dissemination of scientific research documents, whether they are published or not. The documents may come from teaching and research institutions in France or abroad, or from public or private research centers.
L'archive ouverte pluridisciplinaire HAL, est destinée au dépôt et à la diffusion de documents scientifiques de niveau recherche, publiés ou non, émanant des établissements d'enseignement et de recherche français ou étrangers, des laboratoires publics ou privés. 
Scaled-up electrochemical reactor with a fixed bed three-dimensional cathode for electro-Fenton process: Application to the treatment of bisphenol A

Ayman Chmayssem, ${ }^{1,2}$ Samir Taha, ${ }^{3}$ Didier Hauchard ${ }^{1,2} *$

${ }^{1}$ Institut Sciences Chimiques de Rennes, UMR CNRS 6226, École Nationale Supérieure de Chimie de Rennes, 11 allée de Beaulieu, CS 50837, 35708 Rennes Cedex 7

${ }^{2}$ Université Bretagne Loire, 1 place Paul Ricœur, 35000 Rennes

${ }^{3}$ Laboratoire Biotechnologie appliquée (LBA3B), Centre AZM, École doctorale des sciences et technologies, Université Libanaise, Tripoli, Liban.

*corresponding author: didier.hauchard@ensc-rennes.fr 


\begin{abstract}
In this study, we report on the development of an open undivided electrochemical reactor with a compact fixed bed of glassy carbon pellets as three-dimensional cathode for the application of electro-Fenton process. Bisphenol A (BPA) was chosen as model molecule in order to improve its efficiency to the treatment of persistent pollutants. The study of the BPA removal efficiency in function of the applied current intensity was investigated in order to determine the limiting current of $\mathrm{O}_{2}$ reduction (optimal conditions of $\mathrm{H}_{2} \mathrm{O}_{2}$ production at flow rate of $\left.0.36 \mathrm{~m}^{3} \cdot \mathrm{h}^{-1}\right)$ which was $0.8 \mathrm{~A}(0.5 \mathrm{~A} / 100 \mathrm{~g}$ of glassy carbon pellets). Many parameters have been carried out using this electro-Fenton reactor namely degradation kinetics, influence of anodic reactions on DSA, effect of initial pollutant concentration. In the optimal current condition, the global production rate of $\mathrm{H}_{2} \mathrm{O}_{2}$ and ${ }^{\circ} \mathrm{OH}$ was investigated. The yield of electro-Fenton reaction (conversion of $\mathrm{H}_{2} \mathrm{O}_{2}$ to ${ }^{\circ} \mathrm{OH}$ ) was very high (>90\%). The absolute rate of BPA degradation was determined as $4.3 \times$ $10^{9} \mathrm{M}^{-1} \mathrm{~s}^{-1}$. COD, TOC and BOD5 measurements indicated that only few minutes of treatment by electro-Fenton process were needed to eliminate BPA for dilute solutions (10 and $25 \mathrm{mg} . \mathrm{L}^{-1}$ ). In this case, the biodegradability of the treated solutions occurred rapidly. For higher concentration levels, an efficient removal of BPA appeared for treatment time higher than 1 hour and more than 90 minutes were necessary to obtain the biodegradability of BPA solutions. In optimum conditions, the scale-up of the electrochemical reactor applied to electro-Fenton process was suggested and depended on the concentration level of the pollutant. The operating parameters of the scaled-up reactor might be deduced from the new section of each fixed bed exposed to the flow, from values of liquid flow velocity and from the corresponding limiting current density obtained with the reactor at laboratory scale. The compact fixed bed cathode in an open undivided electrochemical reactor appears as an appropriate solution as pre-treatment electro-Fenton process followed by the biological treatment of persistent pollutant.
\end{abstract}

\title{
Keywords
}

Electro-Fenton process, Fixed-bed cathode, Water treatment, Bisphenol A, advanced oxidation process. 


\section{Introduction}

The wastewater treatment including a biological step is often an economical process in comparison with other treatment options. However, the classical biological process is unsuccessful for the removal of effluents containing non-biodegradable organic substances (pesticides, antibiotics, drug residues, alkylphenols...) [1,2]. To avoid the dispersion in the environment of these persistent pollutants, a wide variety of alternative processes has been therefore studied in order to remove such pollution. Among destructive or pretreatment processes, advanced oxidation processes (AOPs) have received great interest in the recent years [3,4]. These processes consisting of the generation of reactive radical species are more often based on the generation of hydroxyl radicals ( $\left.{ }^{\circ} \mathrm{OH}\right)$. This very reactive and non-selective oxidizing agent leads to the degradation of organic pollutants by hydrogen atom abstraction reaction, electron transfer, or electrophilic addition to $\pi$ systems [5-9].

Among AOPs, electro-Fenton process is one of the electrochemical processes that consist in producing Fenton's reagent $\left(\mathrm{Fe}^{2+} / \mathrm{H}_{2} \mathrm{O}_{2}\right)$ in acidic medium $(\mathrm{pH} 3)$ at the cathode by $\mathrm{O}_{2}$ reduction (Equation 1) $[6,10,11]$. The electro-generated $\mathrm{H}_{2} \mathrm{O}_{2}$ species reacts with the added $\mathrm{Fe}^{2+}$ ions to produce hydroxyl radicals $\mathrm{HO}^{\bullet}$ (Equation 2). However, $\mathrm{Fe}^{2+}$ ions are mainly regenerated by the cathodic reduction of $\mathrm{Fe}^{3+}$ ions (Equation 3 ). Thus only the addition of a small catalyst quantity of iron $\left(\mathrm{Fe}^{2+}\right)$ is needed.

$$
\begin{gathered}
\mathrm{O}_{2}+2 \mathrm{H}^{+}+2 \mathrm{e}^{-} \rightarrow \mathrm{H}_{2} \mathrm{O}_{2}\left(\mathrm{E}^{\circ}=0.69 \mathrm{~V} / \mathrm{SHE}\right) \\
\mathrm{Fe}^{2+}+\mathrm{H}_{2} \mathrm{O}_{2} \rightarrow \mathrm{Fe}^{3+}+\mathrm{OH}^{-}+\mathrm{HO}^{\bullet}(\text { Fenton's reaction }) \\
\mathrm{Fe}^{3+}+\mathrm{e}^{-} \rightarrow \mathrm{Fe}^{2+}\left(\mathrm{E}^{\circ}=0.77 \mathrm{~V} / \mathrm{SHE}\right)
\end{gathered}
$$

Moreover, electro-Fenton process has demonstrated a potential capacity of treating persistent chemical pollutants [12-15] and a recent review pointed its interest for wastewater remediation [12]. Various electrochemical cells have been used and employed for the application of electro-Fenton processes and are distinguished by their configuration (divided or undivided compartment), the nature of the cathode which must reduce oxygen in a two-electron process (Carbon-based electrodes (carbon felt, activated carbon fiber ...) and gas-diffusion electrodes) and the nature of anode (BDD, $\left.\mathrm{PbO}_{2}, \mathrm{Pt} . ..\right)$ $[6,11,16]$. By and large, most of the above cited studies presented interesting process efficiencies at laboratory scale. However, these studies suggested reactor configurations and electrodes materials which were not appropriate to scale-up the process to industrial pilot plant. So it appears opportunities to develop new electrochemical reactors that would be able to treat organic pollutants by electro-Fenton process with high flow rates and low cost of electrode materials and electrical energy at semi-pilot or industrial plant. 
Therefore, we have used in this study an undivided electrochemical reactor with a fixed bed of carbon pellets three-dimensional cathode that was developed in a past time by EDF (Électricité de France) to treat aqueous effluent containing heavy metal (Copper,Silver,...) [17]. These reactors (PRIAM family) have been scaled-up to semipilot plant. After modification of the fixed bed cathode (substitution of the graphite carbon by glassy carbon pellets for a better charge transfer kinetic of $\mathrm{O}_{2}$ reduction), we have developed in our laboratory the application of electro-Fenton process with this electrochemical reactor.

Besides, bisphenol A (BPA) is a persistent compound that is not effectively degraded by biological treatment [18]. Different processes were examined for bisphenol A removal from natural water or wastewater, in particular, AOPs $[9,19,20]$. Among these processes, we can found $\mathrm{UV} / \mathrm{H}_{2} \mathrm{O}_{2}$ oxidation [21], photo-Fenton [22], ozonation [23,24], direct electrochemical oxidation [25-29] as well as indirect electrochemical oxidation processes like Fenton and electro-Fenton [30-32] processes. These processes have demonstrated a high bisphenol A abatement efficiency for a small volume treatment. Otherwise, none of the described processes has been really scaled-up. So, it may be interesting to treat BPA as molecule model by electro-Fenton process using the above described reactor.

In this study, we report the development of a new electrochemical reactor that can be applied to treat bisphenol A by electro-Fenton process. This electrochemical reactor was a plug-flow with a fixed bed three-dimensional cathode constituted by glassy carbon pellets. The electro-Fenton process has been optimized to the elimination of BPA and a lot of parameters have been studied. The production of hydrogen peroxide and hydroxyl radicals has been investigated. Mineralization study during BPA treatment was conducted by monitoring of Total Organic Carbon (TOC), Chemical Oxygen Demand (COD) and Biochemical Oxygen Demand (BOD). The biodegradability of BPA was also investigated by the developed electro-Fenton process for different treatment times and at different initial pollutant concentrations.

\section{Experimental}

\subsection{Chemicals and materials}

Glassy carbon pellet material (SIGRADUR ${ }^{\circledR} \mathrm{K}$, high purity) was obtained from HTW (Germany) and has an appropriate average diameter of $3 \mathrm{~mm}$. Bisphenol A used to the preparation of polluted water $\left(\mathrm{C}_{15} \mathrm{H}_{16} \mathrm{O}_{2}, 2\right.$ 2-2-Bis(4-hydroxyphenyl)propane - purity > $99 \%)$ and sodium sulfate used as supporting electrolyte $\left(\mathrm{Na}_{2} \mathrm{SO}_{4}-\right.$ purity $\left.>99 \%\right)$ were purchased from Sigma-Aldrich. Iron (II) sulfate heptahydrate $\left(\mathrm{Fe}_{2} \mathrm{SO}_{4} .7 \mathrm{H}_{2} \mathrm{O}-\right.$ purity 98\%) was obtained from Scharlau chemicals. For mobile phase preparation, acetonitrile (HPLC grade) was also purchased from Sigma-Aldrich for mobile phase preparation. 
Demineralized water was obtained in our laboratory by an appropriate production system (Millipore). Other chemicals used were of analytical grade reagents. All the measurements and experiments were carried out at laboratory temperature.

\subsection{Solution preparation}

Synthetic solutions of bisphenol A were prepared in demineralized water without any organic solvents addition in order to limit the introduction of organic matter only to BPA. The $\mathrm{pH}$ of the solution was adjusted to $2.9 \pm 0.1$ using $\mathrm{H}_{2} \mathrm{SO}_{4}$. The $\mathrm{Na}_{2} \mathrm{SO}_{4}$ was added as supporting electrolyte at the concentration of $0.05 \mathrm{M}$. The Fe (II) was added to the solution at the concentration of $0.5 \mathrm{mM}$.

\subsection{Electro-Fenton process system}

The electrochemical reactor used in this study for electro-Fenton experiments was an open one-compartment reactor in PVC with rectangular geometric dimensions of $14 \mathrm{~cm}$ (L) $x 12 \mathrm{~cm}(\mathrm{l}) \times 17 \mathrm{~cm}(\mathrm{H})$ and a volumic capacity of $1.5 \mathrm{~L}$. The electrochemical reactor is equipped in his middle with a three-dimensional cathode (3D cathode) itself made up of a compact fixed bed of glassy carbon grains and surrounded by 2 DSA mesh anodes $\left(\mathrm{Ti} / \mathrm{RuO}_{2}\right)$ with a gap of $2 \mathrm{~cm}$. The contaminated solutions were treated in batch and a centrifugal pump was used to feed the electrochemical reactor with a constant flow rate fixed by a flow meter (typically $\left.6 \mathrm{~L} \cdot \mathrm{min}^{-1}\left(0.36 \mathrm{~m}^{3} \cdot \mathrm{h}^{-1}\right)\right)$. The three-dimensional cathode has a geometric dimension of $13 \mathrm{~cm} \times 8 \mathrm{~cm} \times 3 \mathrm{~cm}(\mathrm{~L}, \mathrm{~W}$, and $\mathrm{H})$ and filled with glassy carbon pellets $(\approx 155 \mathrm{~g})$. A metal mesh as current collector is placed at the center of the fixed bed. The solution flow is perpendicular to the electrodes and the solution goes through the width of the fixed bed. Also, assuming a plug flow at the level of the cathode, the liquid flow velocity through the fixed bed is estimated at $0.0139 \mathrm{~m} . \mathrm{s}^{-1}$. Air pump and air diffuser were used in the experimental setup to supply the solution continually by oxygen. The sampling at different times was carried out at the outlet side of the cathode.

\subsection{Analytical procedures and materials}

\subsubsection{High Performance Liquid Chromatography}

High performance liquid chromatography (HPLC, Waters ${ }^{\text {TM }} 600$ MILLIPORE system, Waters ${ }^{\mathrm{TM}}$ 600 Pump, Waters ${ }^{\mathrm{TM}} 717$ plus autosampler, Photodiode Array Detection Waters ${ }^{\mathrm{TM}}$ 996) were used. HPLC analyzes were performed on reversed-phase column Waters $\mathrm{C}_{18}$ (Symmetry $4.6 \mathrm{~mm} \times 25 \mathrm{~cm}, 5 \mu \mathrm{m}$ ). The composition of the mobile phase was 40/60 (V/v) Acetonitrile/Ultra-Pure Water. The PAD detector was set at $278 \mathrm{~nm}$ and the flow rate of the mobile phase was fixed at $1 \mathrm{~mL} / \mathrm{min}$. The injection volume in the HPLC system was $50 \mu \mathrm{L}$. Empower 2 Software was used respectively for HPLC control and 
results processing. The retention time of bisphenol A was 4.6 minutes under the abovecited conditions.

\subsubsection{Total Organic Carbon}

Total organic carbon (TOC) measurements were carried out using Shimadzu Total Organic carbon analyzer (TOC- $\mathrm{V}_{\mathrm{CPH}}$ ). Organic carbon compounds were mineralized and converted into $\mathrm{CO}_{2}$, which was detected and measured by a non-dispersive infrared detector (NDIR). Reproducible TOC values were always obtained using the standard non-purgeable organic carbon (NPOC) method. TOC-CONTROL V software (Version 2.10) was used for TOC analyzer control and results processing.

\subsubsection{Chemical Oxygen Demand}

Chemical oxygen demand (COD) measurements were carried out using $\mathrm{HACH}^{\circledR}$ DR/2500 method (8000). COD vials were obtained from Hach Lange (Ref. HI93754B$25)$. Only $2 \mathrm{~mL}$ of the solution were added into the COD vial and oxidized for 2 hours at $150^{\circ} \mathrm{C}$ with dichromate $\left(\mathrm{K}_{2} \mathrm{Cr}_{2} \mathrm{O}_{7}\right)$ at acidic $\mathrm{pH}$ using Hach DRB 200 oven. After COD values were measured using a spectrophotometer $(\mathrm{DR} / 2500)$ at $620 \mathrm{~nm}$ after calibration.

\subsubsection{Biochemical Oxygen Demand}

Biochemical oxygen demand (BOD) measurements were carried out using OxiTop system (from WTW) for 5 days (BOD5) in order to check the biodegradability of BPA and its by-products after treatment by electro-Fenton process. Activated sludge taken from wastewater treatment of the municipality of Rennes was used as source of microorganisms. The method was described in details in previous works[15].

\subsubsection{Determination of hydrogen peroxide production}

For electro-Fenton process, hydrogen peroxide $\left(\mathrm{H}_{2} \mathrm{O}_{2}\right)$ formed by electro-reduction of dissolved $\mathrm{O}_{2}$ at the cathode was determined and quantified by iodometric titration. It consists to dose $\mathrm{H}_{2} \mathrm{O}_{2}$ by the back-titration of the liberated iodine with sodium thiosulfate. The determination of $\mathrm{H}_{2} \mathrm{O}_{2}$ was released without BPA and $\mathrm{Fe}^{\mathrm{II}}$ addition in the medium.

\subsubsection{Determination of hydroxyl radical production}

Hydroxyl radicals $\left({ }^{\circ} \mathrm{OH}\right)$ were determined and quantified indirectly by trapping them with a substrate initially added in excess in the electrolysis medium: the Dimethylsulfoxide (DMSO). As indicated by Tai et al.[33], Dimethylsulfoxide (DMSO) has great advantages as a molecular probe for the detection of the hydroxyl radicals in AOPs: (i) DMSO is highly water soluble to trap most hydroxyl radicals generated in AOPs; (ii) it cannot form complexes with iron ions to influence the detection of ${ }^{\circ} \mathrm{OH}$ in electro-Fenton process, (iii) it is nontoxic at relatively high concentrations and (iv) it is highly reactive 
with the hydroxyl radicals $\left(\mathrm{k}=5 \sim 10 \times 10^{9} \mathrm{~mol} \mathrm{~L}^{-1} \mathrm{~s}^{-1}\right)$. It consists of the fast reaction of DMSO with ${ }^{\circ} \mathrm{OH}$ forming methanesulfinic acid (MSA) and methyl radicals as following[33,34]:

$$
\left(\mathrm{CH}_{3}\right)_{2} \mathrm{SO}+{ }^{\bullet} \mathrm{OH} \rightarrow \mathrm{CH}_{3} \mathrm{SO}_{2} \mathrm{H}+\mathrm{CH}_{3} \cdot
$$

However, a recent study indicates that methanesulfinic acid is only an intermediate product, which also reacted rapidly with hydroxyl radicals leading to methanesulfonic acid formation $\left(\mathrm{k}=6.2 \sim 12 \times 10^{9} \mathrm{~mol} \mathrm{~L}^{-1} \mathrm{~s}^{-1}\right)$ as following to give methanesulfonate $\left(\mathrm{MS}^{-}\right)[34-36]$ :

$\cdot \mathrm{OH} \quad \mathrm{O}_{2}$

$\mathrm{CH}_{3} \mathrm{SO}_{2} \mathrm{H} \rightarrow \rightarrow \mathrm{CH}_{3} \mathrm{SO}_{3}{ }^{-}$

We can consider that methanesulfonate is quite stable as it reacts very slowly with ${ }^{\circ} \mathrm{OH}(\mathrm{k}$ $=0.810^{7} \mathrm{M}^{-1} \mathrm{~s}^{-1}$ ) in comparison with the excess of DMSO. At $\mathrm{pH} 3$, methanesulfonic acid ( $\mathrm{pKa}-1.2)$ is under its conjugated base $\left(\mathrm{MS}^{-}\right)$which has been then quantified by ion chromatography. A series of standard methanesulfonate solutions were prepared and injected in order to establish a calibration curve from 0.1 to $2.5 \mathrm{mM}$. The determination of ${ }^{\circ} \mathrm{OH}$ was released by electro-Fenton experiments without BPA addition in the medium. Ion chromatography (Dionex DX-120) coupled to a conductivity detector was used in this study. Ion chromatography analyzes were performed using anion exchange column Dionex IonPac AS19 $(4 \times 250 \mathrm{~mm})$ and pre-column Dionex IonPac AG19 $(4 \times 50 \mathrm{~mm})$. The eluent gradient was generated using a Dionex EGC-KOH EluGenII cartridge as following: 0-10 min: $10 \mathrm{mM}$ isocratic; 10-25 min: gradient from 10 to $45 \mathrm{mM}$; 25-35 min: $45 \mathrm{mM}$ isocratic with a flow rate of $1 \mathrm{~mL} \cdot \mathrm{min}^{-1}$.

\section{Results and discussion}

Initially the electrochemical reactor used in this study was equipped with a fixed bed of carbon graphite grains (3-5 mm diameter) which presents an irregular surface and a porous structure. The drawback was that BPA molecules and their by-products were adsorbed partially by this material conducting to perturbations in the evaluation of the electro-Fenton process. For this reason, we substituted the carbon graphite bed over a compact fixed bed of glassy carbon pellets. With this non-porous material, no adsorption occurred and the decreasing of the BPA concentration could be attributed to its degradation by the electrochemical process. With this newly fixed bed cathode, the effect of the applied current intensity on the removal efficiency of BPA during the treatment by electro-Fenton process has been investigated. The removal efficiency can be defined as following: $\left[\left(\mathrm{C}_{0}-\mathrm{C}_{\mathrm{t}}\right) \times 100\right] / \mathrm{C}_{\mathrm{t}}$, where $\mathrm{C}_{\mathrm{t}}$ is the concentration of bisphenol $\mathrm{A}$ after time of treatment $(\mathrm{t})$ and $\mathrm{C}_{0}$ is the initial concentration of bisphenol A before treatment(about 150 $\left.\mathrm{mg} . \mathrm{L}^{-1}\right)$. Figure 2 illustrates the variation of removal efficiency according to time for different applied current intensities from 0.2 A to 1.2 A. However, an improvement in the 
removal efficiency was observed with an increase of the applied current intensity till 0.8 1.0 A. For greater intensities, the treatment appears less efficient indicating that the applied current intensity is higher than the limiting current for $\mathrm{O}_{2}$ reduction according to equation (1) and that a part of $\mathrm{H}_{2} \mathrm{O}_{2}$ produced is reduced in $\mathrm{H}_{2} \mathrm{O}$ (equation 4) with a global 4 electrons reduction process of $\mathrm{O}_{2}$. Also, the limiting current intensity in the hydrodynamic conditions corresponding to $6 \mathrm{~L} \cdot \mathrm{min}^{-1}$ should be estimated at about $0.9 \mathrm{~A}$ and thereafter, an optimized current intensity set at $0.8 \mathrm{~A}(0.51 \mathrm{~A} / 100 \mathrm{~g}$ of glassy carbon pellets) for the following experiments of the treatment by electro-Fenton process.

$$
\mathrm{H}_{2} \mathrm{O}_{2}+2 \mathrm{H}^{+}+2 \mathrm{e}^{-} \rightarrow 2 \mathrm{H}_{2} \mathrm{O}
$$

Moreover, the production of hydrogen peroxide $\left(\mathrm{H}_{2} \mathrm{O}_{2}\right)$ and hydroxyl radicals $\left({ }^{\circ} \mathrm{OH}\right)$ by electro-Fenton process in the optimized current conditions has been investigated. Figure 3 shows the global production of $\mathrm{H}_{2} \mathrm{O}_{2}$ versus time by applying $0.8 \mathrm{~A}$ in absence of BPA. During 60 min of electrolysis the variation of the $\mathrm{H}_{2} \mathrm{O}_{2}$ concentration is linear indicating a constant production of $\mathrm{H}_{2} \mathrm{O}_{2}$ with a global production rate of $0.06 \mathrm{mmol} . \mathrm{min}^{-1}$. Considering the theoretical charge quantity for $0.8 \mathrm{~A}$, this rate value corresponds to a faradic efficiency of $25 \%$ for global production of $\mathrm{H}_{2} \mathrm{O}_{2}$. This low value could be explained by the partial anodic oxidation on DSA of $\mathrm{H}_{2} \mathrm{O}_{2}$ produced initially at the cathode. However, during electro-Fenton process, the produced hydrogen peroxide reacts quickly with $\mathrm{Fe}^{2+}$ to give radical hydroxyl in the vicinity of the cathode avoided like that the oxidation of $\mathrm{H}_{2} \mathrm{O}_{2}$ at the anode. In electro-Fenton conditions (presence of $\mathrm{Fe}^{2+}$ ), the production of radical hydroxyl could be estimated by addition of an excess of a molecular probe, the DMSO which is highly reactive with the hydroxyl radicals giving methanesulfonate as oxidized by-product (for more details see $\S 2.4 .6$ and reference therein). The production of methanesulfonate for $60 \mathrm{~min}$ of the electro-Fenton treatment at $0.8 \mathrm{~A}$ is followed each $5 \mathrm{~min}$ by ionic chromatography (Figure 4 ). The peak of methanesulfonate $\left(t_{R}=4.2 \mathrm{~min}\right)$ presents a good resolution and is well separated from the large sulfate peak $\left(t_{R}=8.5 \mathrm{~min}\right)$. After a few minutes the concentration of $\mathrm{MS}^{-}$increases linearly with treatment time indicating a constant production of ${ }^{\circ} \mathrm{OH}$ with a calculated global rate of $0.055 \mathrm{mmol} . \mathrm{min}^{-1}$. In a primary approximation, considering the global production of $\mathrm{H}_{2} \mathrm{O}_{2}$, it appears that the production yield is relatively high (>90\%) indicating a good efficiency of this compact fixed bed electrochemical reactor to conduct electro-Fenton process.

However, in order to consider potential anodic reactions during the EF process, anodic oxidation of $\mathrm{H}_{2} \mathrm{O}_{2}$ and BPA have been studied by cyclic voltammetry at a homemade DSA microelectrode (Figure 5).At DSA the oxidation of water in $\mathrm{O}_{2}$ appears at about 1.2 $\mathrm{V} / \mathrm{Ag} / \mathrm{AgCl}$ while $\mathrm{H}_{2} \mathrm{O}_{2}$ oxidation occurs at lower potential (350 mV below). BPA presents 2 oxidation peaks respectively at 0.6 and $0.9 \mathrm{~V} / \mathrm{Ag} / \mathrm{AgCl}$. This indicates that both BPA and electro-generated $\mathrm{H}_{2} \mathrm{O}_{2}$ could be oxidized at the DSA anode during the 
process. To ensure of the impact on the electro-Fenton process of these potential reactions, several experiments were conducted in presence or in absence of $\mathrm{O}_{2}$ and $\mathrm{Fe}^{\mathrm{II}}$ (Figure 6). In the condition of absence of $\mathrm{H}_{2} \mathrm{O}_{2}$ production (without dissolved $\mathrm{O}_{2}$, under $\mathrm{N}_{2}$ atmosphere), even after 50 minutes, the removal of BPA is extremely low, indicating a negligible part of BPA degradation due to its anodic oxidation $(<10 \%$ of the BPA removal). The potential of the electrochemical cell during the electrolysis of BPA solution remains constant and doesn't shift to higher values (phenomenon arising when passivation of the anode occurs). Furthermore, in condition of acidic $\mathrm{pH}$ and with DSA anode, we don't observe inactivation of the anode by polymerization of BPA similarly to Tanaka et al. in their study ( $\mathrm{pH}=2$ and $\mathrm{SnO} 2 / \mathrm{Ti}$ anode) [40]. In the conditions of $\mathrm{H}_{2} \mathrm{O}_{2}$ production (presence of $\mathrm{O}_{2}$ without $\mathrm{Fe}^{2+}$ addition) the removal of BPA increases slightly in function of the time which corresponds to the increasing of the $\mathrm{H}_{2} \mathrm{O}_{2}$ production and to the oxidation of BPA by hydrogen peroxide with a low kinetic in comparison of electroFenton conditions (not exceed 20\%). All these results confirm that Fenton reaction is principally causing the degradation of BPA during electrolysis when conditions of the electro-Fenton process are applied.

A study of EF treatment in function of the initial BPA concentration (from 10 to 150 mg. $\mathrm{L}^{-1}$ ) was conducted for 90 minutes at $0.8 \mathrm{~A}$ (Figure 7 ). While for $150 \mathrm{mg} . \mathrm{L}^{-1}$ of BPA 90 minutes are necessary to rich a removal efficiency of $80 \%$, the duration of the treatment to obtain $99 \%$ of removal is as soon shorter and shorter as the concentration decreases. For $10 \mathrm{mg} . \mathrm{L}^{-1}$, only 12 minutes are sufficient to ensure $99 \%$ of BPA removal. Because it is difficult to set samples of interval time lower than 2 minutes for BPA concentration measurement, we can extrapolate that, for $1 \mathrm{mg} . \mathrm{L}^{-1}$, only a few minutes of treatment should be sufficient for a total degradation of BPA. This indicates that the configuration of this electro-Fenton reactor is partially interesting to treat micropollutions of BPA by a single pass of the solution through the fixed bed cathode.

However, it is generally conceded that the reaction of ${ }^{\circ} \mathrm{OH}$ with phenolic compounds could be primarily considered as a pseudo-first-order reaction suggesting a direct attack of hydroxyl radicals on BPA and considering that hydroxyl radical is continuously produced and destroyed at a similar rate to attain a steady-state concentration [6]. Taking into account this hypothesis, the apparent constant rate $\left(\mathrm{K}_{\mathrm{app}}\right)$ of BPA could be calculated using the theoretical equation of a pseudo order reaction. Figure 8 shows the variation of $\mathrm{Ln}\left(\mathrm{C}_{0} / \mathrm{C}_{\mathrm{t}}\right)$ in function of time during the first $45 \mathrm{~min}$ of treatment of BPA $\left(150 \mathrm{mg} . \mathrm{L}^{-1}\right)$ by electro-Fenton process. As expected, a linear relation $\left(r^{2}>0.99\right)$ is observed with a slope of $0.016 \mathrm{~min}^{-1}$ corresponding to the value of $\mathrm{K}_{\mathrm{app}}$.

On the basis of this model, the absolute constant rate of BPA toward ${ }^{\circ} \mathrm{OH}$ was determined by the competition kinetics method consisting of carrying out an electro-Fenton treatment with a solution containing equimolar concentrations of BPA and benzoic acid (HBA) [6]. 
HBA was used as standard competitor for the determination of the absolute rate constant of BPA oxidation by hydroxyl radicals. The concentration decay of both substrates was followed and measured by HPLC analysis. By plotting the variation of $\operatorname{Ln}\left([\mathrm{BPA}]_{0} /\right.$ $\left.[\mathrm{BPA}]_{\mathrm{t}}\right)=\mathrm{f}\left(\mathrm{Ln}\left([\mathrm{HBA}]_{0} /[\mathrm{HBA}]_{\mathrm{t}}\right)\right)($ Figure 9$)$ a linear relation $\left(\mathrm{r}^{2}>0.99\right)$ is obtained with a slope of 0.549 corresponding to the value of $\left(\mathrm{K}_{(\mathrm{BPA})} / \mathrm{K}_{(\mathrm{HBA})}\right)$ ratio. Also, from the known value $\mathrm{K}_{(\mathrm{HBA})}\left(4.3 \times 10^{9} \mathrm{M}^{-1} \mathrm{~s}^{-1}\right)$ the absolute rate constant of BPA can be calculated as $\mathrm{K}_{(\mathrm{BPA})}=2.4 \times 10^{9} \mathrm{M}^{-1} \mathrm{~s}^{-1}$. This value is close to the absolute constant rate obtained for the reaction between phenolics compounds and hydroxyl radicals[8,37,38].

A measurement of a good removal of BPA is not sufficient to evaluate treatment performances of this electro-Fenton process. By-products have to be further oxidized in order to obtain their biodegradability or their mineralization. The mineralization of BPA by electro-Fenton process was also studied by monitoring the Total Organic Carbon (TOC) and the Chemical Oxygen Demand (COD) at different treatment times (30, 60 and $90 \mathrm{~min}$ ). Figure 10 shows the variation of COD and TOC abatement versus time of EF treatment for different initial concentrations of BPA (from $10 \mathrm{mg} / \mathrm{L}$ to $150 \mathrm{mg} / \mathrm{L}$ ). It appears that, COD and TOC abatement increase with treatment time and the diminution of BPA initial concentration. For high concentrations of BPA (100 and $\left.150 \mathrm{mg} . \mathrm{L}^{-1}\right)$ the efficiency of the treatment is weak with values of COD and TOC respectively $18 \%$ and $7 \%$. On the other hand, good performances were obtained for low concentrations of BPA. Thus, for $10 \mathrm{mg} . \mathrm{L}^{-1}$, near $100 \%$ of COD and $42 \%$ of COT are removed over a $90 \mathrm{~min}$ time period of treatment indicating that about $50 \%$ of BPA was mineralized. The residual TOC was corresponding to small organic acids (succinic, malic, acetic, formic, oxalic acids, and results no given here) as by-products. These aliphatic acids are very difficult to oxidize and the total mineralization will need many hours of treatment as we can find in many other studies for other pollutants[5, 13,39$]$. It can be noted on figure 10 a difference of TOC and COD removals, especially for the lowest concentrations of BPA. This phenomenon can be explained by taking into account the concept of the mean oxidation number of carbon presented in detail by F. Vogel et al. [41]. For BPA, the mean oxidation number of carbon (MOC) is equal to -0.8 and becomes +4 for $\mathrm{CO}_{2}$, the most oxidized form of carbon. For a molecule there is a relation between MOC, COT and COD values. The theorical COD/TOC ratio before electro-Fenton treatment of BPA is equal to 3.2 (for example with a concentration of $150 \mathrm{mg} . \mathrm{L}^{-1} \mathrm{TOC}_{\text {theo }}=118.4 \mathrm{mgC} . \mathrm{L}^{-1}$ and $\mathrm{COD}_{\text {theo }}=379 \mathrm{mg} \mathrm{O}_{2} \cdot \mathrm{L}^{-1}$ ). For the highest concentrations of BPA, this ratio remains experimentally close to the theorical value of 3.2 during the treatment indicating that $\mathrm{EF}$ byproducts present global negative MOC values. For the lowest BPA concentrations (10 and $25 \mathrm{mg} . \mathrm{L}^{-1}$ ) the COD/TOC ratios become rapidly lower than 3 during the treatment and the calculated MOC values are positives and tend toward a value of +3 . This indicates an effective degradation of BPA molecules into small carboxylic acids which present MOC values between +1 and +3 (succinic acid: +1.5 ; malic acid: +1.75 ; formic acid: +2 ; oxalic acid: +3 ). Also these small organic acids lead to small values of COD 
(weak oxidability) while TOC values remain significant with TOC removals lower than $50 \%$.

In the same electrolysis conditions, the improvement of BPA biodegradability was also investigated by monitoring the Biochemical Oxygen Demand (BOD5) at the end of treatment $(90 \mathrm{~min})$. Figure 11 shows the variation of $\mathrm{BOD}_{5} / \mathrm{COD}$ ratio according to the initial concentration of BPA after treatment by electro-Fenton process at $0.8 \mathrm{~A}$. This ratio should be higher than 0.4 to qualify the treated solution as a biodegradable effluent. A high biodegradability enhancement was particularly observed for the dilute contaminated solutions of BPA (10 and $25 \mathrm{mg} . \mathrm{L}^{-1}$ ). These results highlight the efficiency of electroFenton process in the treatment of BPA where only few minutes of treatment was effectively needed to improve the biodegradability and make the charge biodegradable.

For the scale-up of process to semi-pilot plant, two cases must be first considered depending in the concentration level of the pollutant. For the highest concentrations (> mg. $\mathrm{L}^{-1}$ ), a batch reactor should be considered with a lot of fixed bed cathodes in a series with a perpendicular flow to the cathode surface, through each fixed bed in succession with DSA anodes. The size of the fixed bed is depending on the flow rate and the volume of solution to be treated. In all cases, the applied current intensity should be $0.51 \mathrm{~A}$ for $100 \mathrm{~g}$ of glassy carbon pellets $\left(0.012 \mathrm{~A} . \mathrm{cm}^{-2}\right.$ considering the section of the fixed bed exposed to the flow). For traces pollutant levels $\left(<\mathrm{mg} . \mathrm{L}^{-1}\right)$, it should be possible to apply direct treatment with a single pass in an appropriate sized electro-Fenton reactor constituted with fixed bed cathodes in a series. The scale-up depends on the flow rate of the solution which is limited to acceptable values $\left(\mathrm{a}\right.$ few $\mathrm{m}^{3} \cdot \mathrm{h}^{-1}$ ). For batch treatment, the treatment duration depends on the pollutant charge to reach its biodegradability. For direct treatment, the biodegradability should achieve after passing through the electroFenton reactor. For an easier scale-up, it is preferable to maintain constant the thickness of the bed, with the value corresponding to the 3D cathode used in the laboratory reactor $(2 \mathrm{~cm})$. Under these conditions, considering the same limiting current density and liquid flow velocity as those obtained with the laboratory reactor $\left(0.012 \mathrm{~A} . \mathrm{cm}^{-2}\right.$ and $1.39 \mathrm{~cm} . \mathrm{s}^{-1}$ $\left.\left(6 \mathrm{~L} . \mathrm{min}^{-1}\right)\right)$, the limiting current intensity and the flow rate might be deduced from the new section of the fixed bed crossed over by the electrolyte. Indeed, in the case of a fixed bed, for the same liquid flow velocity $(v)$, the Reynolds number is the same $\left(\operatorname{Re}=v^{*} d p / n\right)$ and consequently the mass transfer coefficient $\left(\mathrm{km}=\mathrm{A}^{*} \mathrm{v}^{\mathrm{b}}\right)$ where dp is the particle diameter, $\mathrm{n}$ the kinematic viscosity, $\mathrm{A}$ and $\mathrm{b}$ constants $[42,43]$. The limiting current density, $\mathrm{J}_{\mathrm{lim}}$, is function of mass transfer coefficient $\left(\mathrm{J}_{\lim }=\mathrm{km} * \mathrm{n}^{*} \mathrm{~F}^{*} \mathrm{C}_{0}\right.$ with $\mathrm{n}$ : number of exchange electrons, F: Faraday constant, $\mathrm{C}_{0}$ : concentration of dissolved oxygen). Therefore, in this case, for a scale-up of the reactor, it is not necessary to determine the mass transfer coefficient as it remains difficult to estimate owing to the non-regular and disperse form of the vitreous carbon pellets.

\section{Conclusion}


In conclusion, the application of electro-Fenton process in an undivided electrochemical reactor with a three-dimensional cathode constituted by a fixed bed of glassy carbon pellets has demonstrated its capability to treat bisphenol A and to reduce the charge of non-biodegradable pollutant. This study with a laboratory scale reactor has allowed to obtain the optimum conditions for the application of electro-Fenton process (production of $\left.{ }^{\circ} \mathrm{OH}\right)$ and to ensure the scale-up of the reactor at pilot plant in order to achieve the biodegradability of the polluted solutions. The scale-up depends on the pollutant concentration levels and, in all cases, appears as an appropriate solution for pre-treatment process prior to the biological treatment of wastewater.

\section{References}

[1] K.R. Kim, G. Owens, S.I. Kwon, K.H. So, D.B. Lee, Y.S. Ok, Occurrence and environmental fate of veterinary antibiotics in the terrestrial environment, Water. Air. Soil Pollut. 214 (2011) 163-174.

[2] C. Adams, M. Asce, Y. Wang, K. Loftin, M. Meyer, Removal of Antibiotics from Surface and Distilled Water in Conventional Water Treatment Processes, J. Environ. Eng. 128 (2002) 253-260.

[3] N. Oturan, E.D. Van Hullebusch, H. Zhang, L. Mazeas, H. Budzinski, K. Le Menach, M. a. Oturan, Occurrence and removal of organic micropollutants in landfill leachates treated by electrochemical advanced oxidation processes, Environ. Sci. Technol. (2015) 151001145245006.

[4] I. Oller, S. Malato, J.A. Sànchez-Pérez, Combination of Advanced Oxidation Processes and biological treatments for wastewater decontamination-A review, Sci. Total Environ. 409 (2011) 4141-4166.

[5] A. Ozcan, Y. Sahin, M.A. Oturan, Complete removal of the insecticide azinphosmethyl from water by the electro-Fenton method - A kinetic and mechanistic study, Water Res. 47 (2013) 1470-1479.

[6] E. Brillas, I. Sirés, M. a Oturan, Electro-Fenton process and related electrochemical technologies based on Fenton's reaction chemistry, Chem. Rev. 109 (2009) 6570-6631.

[7] S. Baig, P. Mouchet, Oxydation et réduction appliquées au traitement de l'eau Ozone - Autres et appareillage oxydants - Oxydation avancée - Réducteurs, Tech. L’ingénieur. (2010).

[8] F. Zaviska, P. Drogui, G. Mercier, J.-F. Blais, Procédés d'oxydation avancée dans le traitement des eaux et des effluents industriels: Application à la dégradation des polluants réfractaires, Rev. Des Sci. L’eau. 22 (2009) 535-563.

[9] S.C. Bouafia, R. Alloune, Procédé d'oxydation avancée pour le traitement des eaux usées: Principe et applications, Rev. Des Energies Renouvelables. 07 (2007) 163-170.

[10] C. Jiang, J. Zhang, Progress and prospect in electro-Fenton process for wastewater treatment, J. Zhejiang Univ. Sci. A. 8 (2007) 1118-1125. 
[11] P.V. Nidheesh, R. Gandhimathi, Trends in electro-Fenton process for water and wastewater treatment: An overview, Desalination. 299 (2012) 1-15.

[12] F.C. Moreira, R.A.R. Boaventura, E. Brillas, V.J.P. Vilar, Electrochemical advanced oxidation processes: A review on their application to synthetic and real wastewaters, Appl. Catal. B Environ. 202 (2017) 217-261.

[13] D. Mansour, F. Fourcade, I. Soutrel, D. Hauchard, N. Bellakhal, A. Amrane, Mineralization of synthetic and industrial pharmaceutical effluent containing trimethoprim by combining electro-Fenton and activated sludge treatment, J. Taiwan Inst. Chem. Eng. 53 (2015) 58-67.

[14] D. Mansour, F. Fourcade, I. Soutrel, D. Hauchard, N. Bellakhal, A. Amrane, Relevance of a combined process coupling electro-Fenton and biological treatment for the remediation of sulfamethazine solutions - Application to an industrial pharmaceutical effluent, Comptes Rendus Chim. 18 (2014) 39-44.

[15] D. Mansour, F. Fourcade, N. Bellakhal, M. Dachraoui, D. Hauchard, A. Amrane, Biodegradability Improvement of Sulfamethazine Solutions by Means of an electro-Fenton Process, Water, Air, Soil Pollut. 223 (2011) 2023-2034.

[16] E. Rosales, M. Pazos, M.A. Sanroman, Advances in the Electro-Fenton Process for Remediation of Recalcitrant Organic Compounds, Chem. Eng. Technol. 35 (2012) 609-617.

[17] O. Leclerc, C. Lahitte, N. Chhim, Method and an electrochemical installation for treating aqueous effluent containing a heavy metal, 1993.

[18] B. Gözmen, M. a. Oturan, N. Oturan, O. Erbatur, Indirect Electrochemical Treatment of Bisphenol A in Water via Electrochemically Generated Fenton's Reagent, Environ. Sci. Technol. 37 (2003) 3716-3723.

[19] F. Zaviska, P. Drogui, G. Mercier, J.-F. Blais, Procédés d'oxydation avancée dans le traitement des eaux et des effluents industriels: Application à la dégradation des polluants réfractaires, Rev. Des Sci. L’eau. 22 (2009) 535-564.

[20] N. Serpone, S. Horikoshi, A. V. Emeline, Microwaves in advanced oxidation processes for environmental applications. A brief review, J. Photochem. Photobiol. C Photochem. Rev. 11 (2010) 114-131.

[21] P.-J. Chen, E.J. Rosenfeldt, S.W. Kullman, D.E. Hinton, K.G. Linden, Biological assessments of a mixture of endocrine disruptors at environmentally relevant concentrations in water following UV/H2O2 oxidation, Sci. Total Environ. 376 (2007) 18-26.

[22] H. Katsumata, S. Kawabe, S. Kaneco, T. Suzuki, K. Ohta, Degradation of bisphenol A in water by the photo-Fenton reaction, J. Photochem. Photobiol. A Chem. 162 (2004) 297-305.

[23] K.S. Tay, N.A. Rahman, M. Radzi, B. Abas, Degradation of bisphenol A by ozonation : rate constants, influence of inorganic anions, and by-products, J. Sci. Technol. 6 (2012) 77-94.

[24] Z. Qiang, Y. Nie, W. Ben, J. Qu, H. Zhang, Degradation of endocrine-disrupting chemicals during activated sludge reduction by ozone, Chemosphere. 91 (2013) 
$366-373$.

[25] H. Kuramitz, M. Matsushita, S. Tanaka, Electrochemical removal of bisphenol A based on the anodic polymerization using a column type carbon fiber electrode, Water Res. 38 (2004) 2330-2337.

[26] J. Zhao, C. Zhu, J. Lu, C. Hu, S. Peng, T. Chen, Electro-catalytic degradation of bisphenol A with modified Co3O4/ $\beta-\mathrm{PbO} 2 / \mathrm{Ti}$ electrode, Electrochim. Acta. 118 (2014) 169-175.

[27] H. Lin, J. Wu, H. Zhang, Degradation of bisphenol A in aqueous solution by a novel electro/Fe3+/peroxydisulfate process, Sep. Purif. Technol. 117 (2013) 1823.

[28] M.F. Brugnera, K. Rajeshwar, J.C. Cardoso, M.V.B. Zanoni, Bisphenol A removal from wastewater using self-organized $\mathrm{TiO} 2$ nanotubular array electrodes, Chemosphere. 78 (2010) 569-575.

[29] Y. Cui, X. Li, G. Chen, Electrochemical degradation of bisphenol A on different anodes, Water Res. 43 (2009) 1968-1976.

[30] S. Yuan, N. Gou, A.N. Alshawabkeh, A.Z. Gu, Efficient degradation of contaminants of emerging concerns by a new electro-Fenton process with Ti/MMO cathode, Chemosphere. 93 (2013) 2796-2804.

[31] M.J. Rivero, E. Alonso, S. Dominguez, P. Ribao, R. Ibañez, I. Ortiz, A. Irabien, Kinetic analysis and biodegradability of the Fenton mineralization of bisphenol A, J. Chem. Technol. Biotechnol. 89 (2014) 1228-1234.

[32] J. Sajiki, J. Yonekubo, Inhibition of seawater on bisphenol A (BPA) degradation by Fenton reagents, Environ. Int. 30 (2004) 145-150.

[33] C. Tai, J. Peng, J. Liu, G. Jiang, H. Zou, Determination of hydroxyl radicals in advanced oxidation processes with dimethyl sulfoxide trapping and liquid chromatography, Anal. Chim. Acta. 527 (2004) 73-80.

[34] Y. Lee, C. Lee, J. Yoon, Kinetics and mechanisms of DMSO (dimethylsulfoxide) degradation by UV / H2O2 process, Water Res. 38 (2004) 2579-2588.

[35] H. Bardouki, M. Barcellos, N. Mihalopoulos, W. Palm, C. Zetzsch, Kinetics and mechanism of the oxidation of dimethylsulfoxide (DMSO) and methanesulfinate (MSI-) by OH radicals in aqueous medium, Atmos. Environ. 36 (2002) 46274634.

[36] Y. Zuo, Light-induced formation of hydroxyl radicals in fog waters determined by an authentic fog constituent, hydroxymethanesulfonate, Chemosphere. 51 (2003) 175-179.

[37] P. Mazellier, J. Leverd, Transformation of 4-tert-octylphenol by UV irradiation and by an $\mathrm{H} 2 \mathrm{O} 2 / \mathrm{UV}$ process in aqueous solution, Photochem. Photobiol. Sci. 2 (2003) 946-953.

[38] S. Trabelsi, N. Oturan, N. Bellakhal, M.A. Oturan, Electrochemical Oxidation of Phthalic Anhydryde in Aqueous Medium by Electro-Fenton Process, J. Environ. Eng. Manag. 19 (2009) 291-297. 
[39] K. Ayoub, S. Nélieu, E.D. Van Hullebusch, J. Labanowski, I. Schmitz-Afonso, A. Bermond, M. Cassir, Electro-Fenton removal of TNT: Evidences of the electrochemical reduction contribution, Appl. Catal. B Environ. 104 (2011) 169-176.

[40] S. Tanaka, Y. Nakata, T. Kimura, Y. Ustiawati, M. Kawasaki, H. Kuramitz, Electrochemical decomposition of bisphenol A using Pt/Ti and SnO2/Ti anodes, J. Appl. Electrochem. 32 (2002) 197-201

[41] F. Vogel, J. Harf, A. Hug, P. R. Von Rohr, The mean oxidation number of carbon (MOC) - A useful concept for describing oxidation processes, Wat. Res. 34 (2000) 2689-2702.

[42] M. Benzina. S. Gabsi, G. Lacoste, Liquid-solid transfer coefficient by an electrochemical technique, J. Tunisian Chem. Soc. 3(2) (1991) 125-140

[43] G. H. Sedahmed, Mass Transfer Behaviour of a Fixed Bed Electrochemical Reactor with a Gas Evolving Upstream Counter Electrode,Can.J.Chem. Eng. 74 (1996) 487-492.
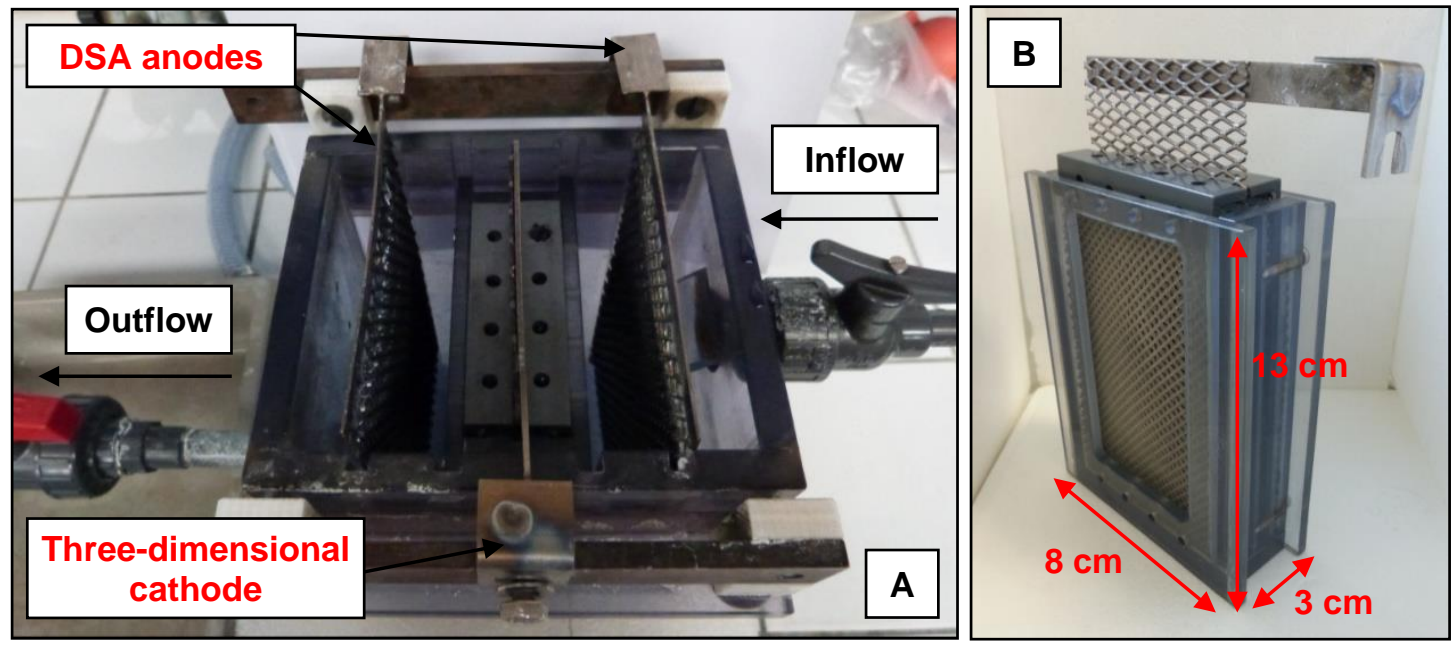

Fig. 1: Pictures of the open one-compartment electrochemical reactor for the application of electroFenton process (A) and the associated fixed bed three-dimensional cathode (B) 


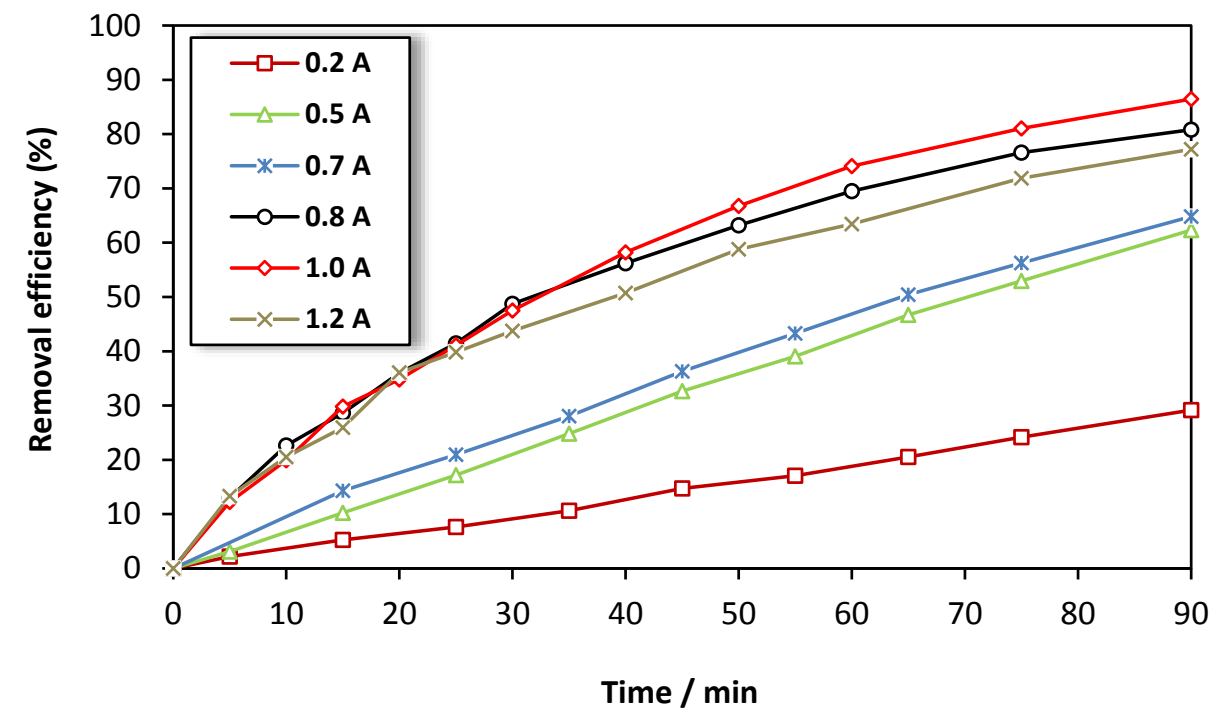

Fig. 2: Effect of the applied current intensity on the removal efficiency of BPA for treatments by electro-Fenton process. Experimental conditions: $[\mathrm{BPA}]=150 \mathrm{mg} \cdot \mathrm{L}^{-1},\left[\mathrm{FeSO}_{4}\right]=0.5 \mathrm{mM},\left[\mathrm{Na}_{2} \mathrm{SO}_{4}\right]$ $=0.05 \mathrm{M}, \mathrm{pH}=2.9 \pm 0.1$, Flow rate $=6 \mathrm{~L} \cdot \mathrm{min}^{-1}$ 


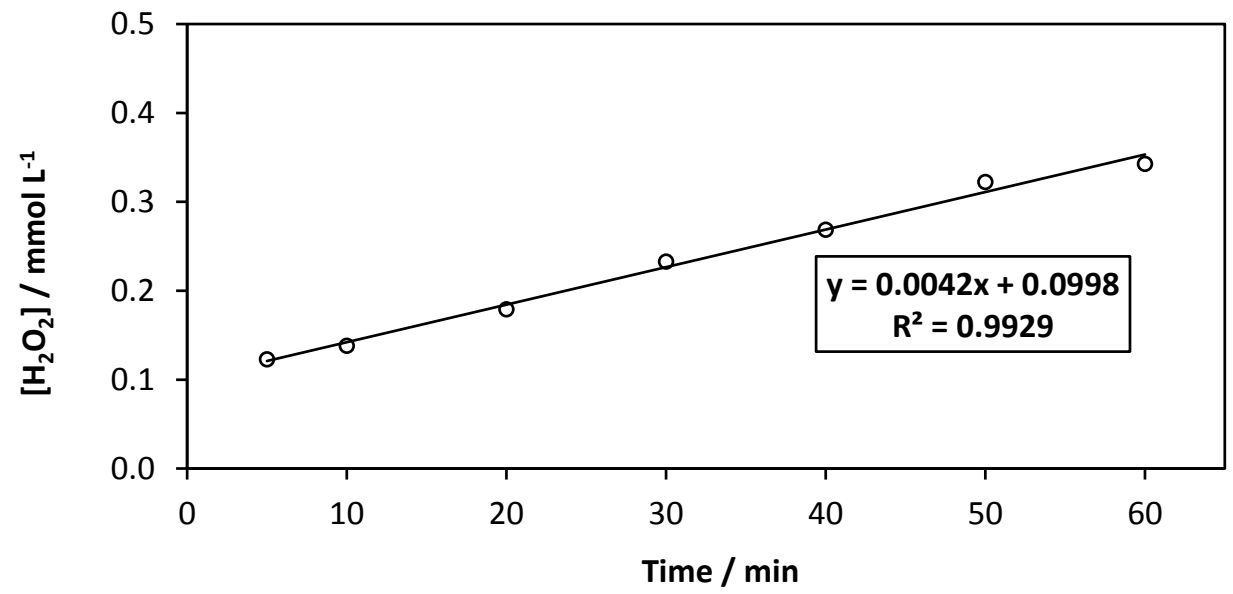

Fig. 3: Production of $\mathrm{H}_{2} \mathrm{O}_{2}$ during electro-Fenton process in absence of $\mathrm{Fe}^{\mathrm{II}}$. Experimental conditions: $\mathrm{I}=0.8 \mathrm{~A},\left[\mathrm{Na}_{2} \mathrm{SO}_{4}\right]=0.05 \mathrm{M}, \mathrm{pH}=2.9 \pm 0.1$, Flow rate $=6 \mathrm{~L} \cdot \mathrm{min}^{-1}$

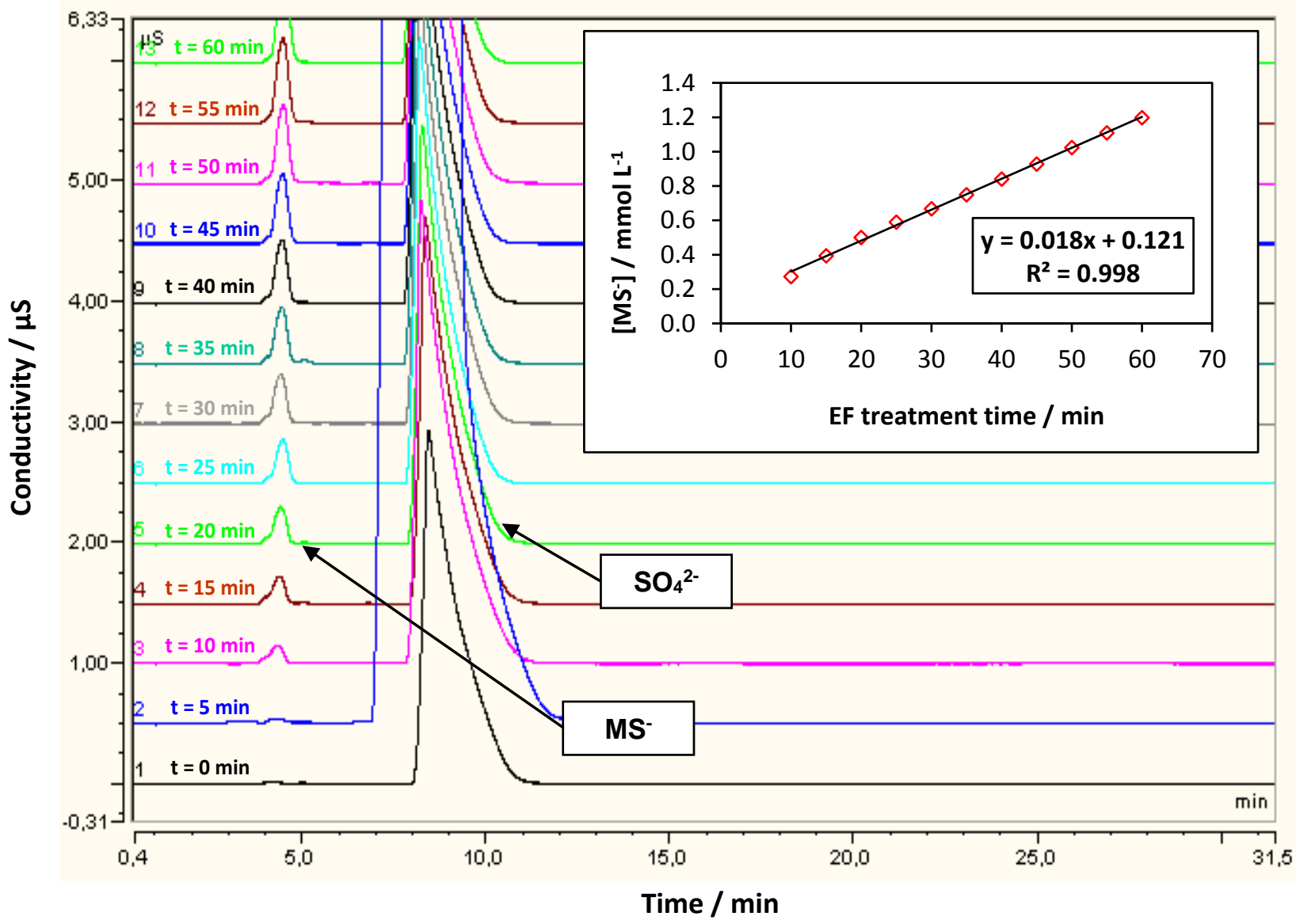

Fig. 4: Monitoring of methanesulfonate production by ion chromatography during electro-

Fenton process with DMSO as molecular probe of ${ }^{\circ} \mathrm{OH}$ production. Experimental conditions: $\mathrm{I}=$ $0.8 \mathrm{~A},\left[\mathrm{FeSO}_{4}\right]=0.5 \mathrm{mM},\left[\mathrm{Na}_{2} \mathrm{SO}_{4}\right]=1 \mathrm{mM}, \mathrm{pH}=2.9 \pm 0.1$, Flow rate $=6{\mathrm{~L} . \mathrm{min}^{-1}}^{-1}$ 


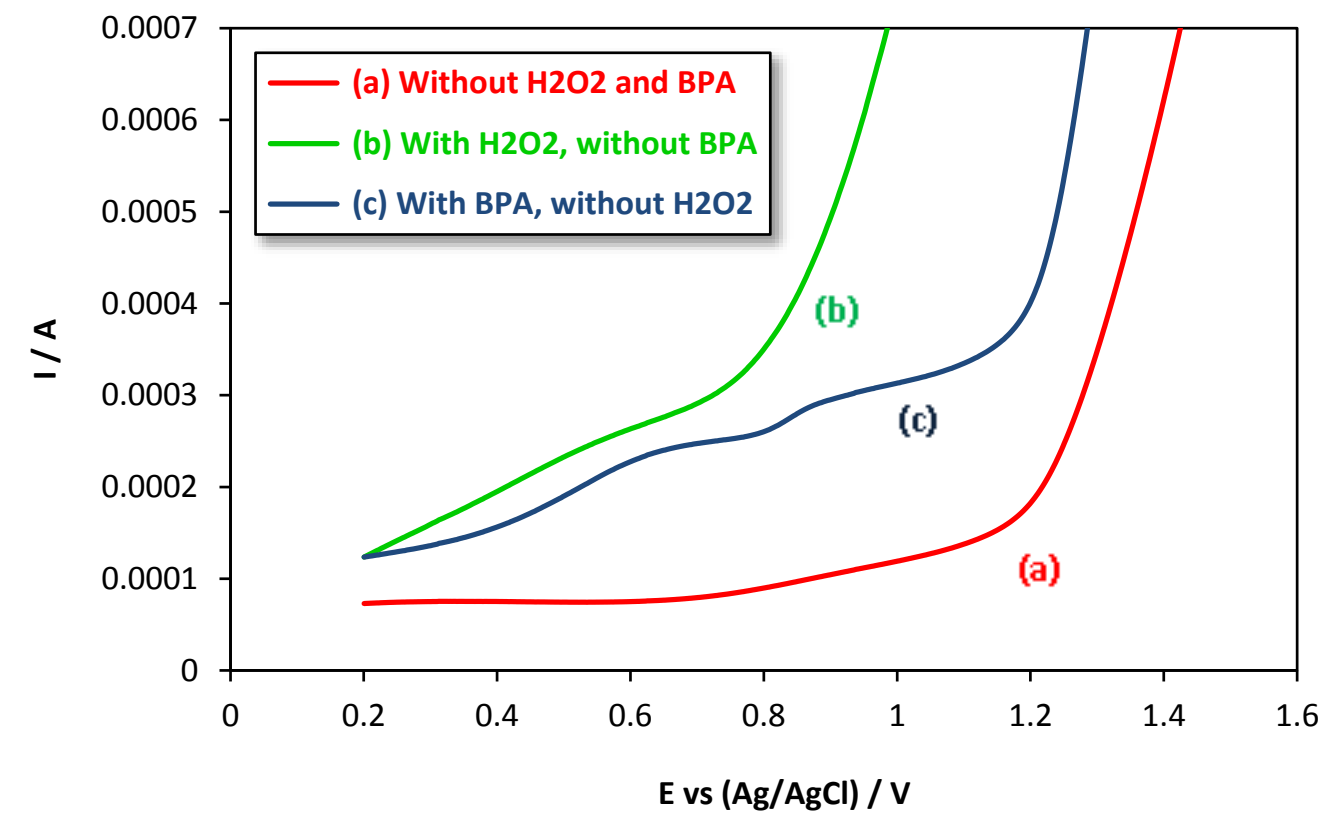

Fig. 5: Cyclic voltammograms of $\mathrm{H}_{2} \mathrm{O}_{2}$ and BPA at DSA microelectrode material. Experimental conditions: $\left[\mathrm{Na}_{2} \mathrm{SO}_{4}\right]=0.05 \mathrm{M}, \mathrm{pH}=2.9 \pm 0.1, v=0.05 \mathrm{~V} / \mathrm{s}$

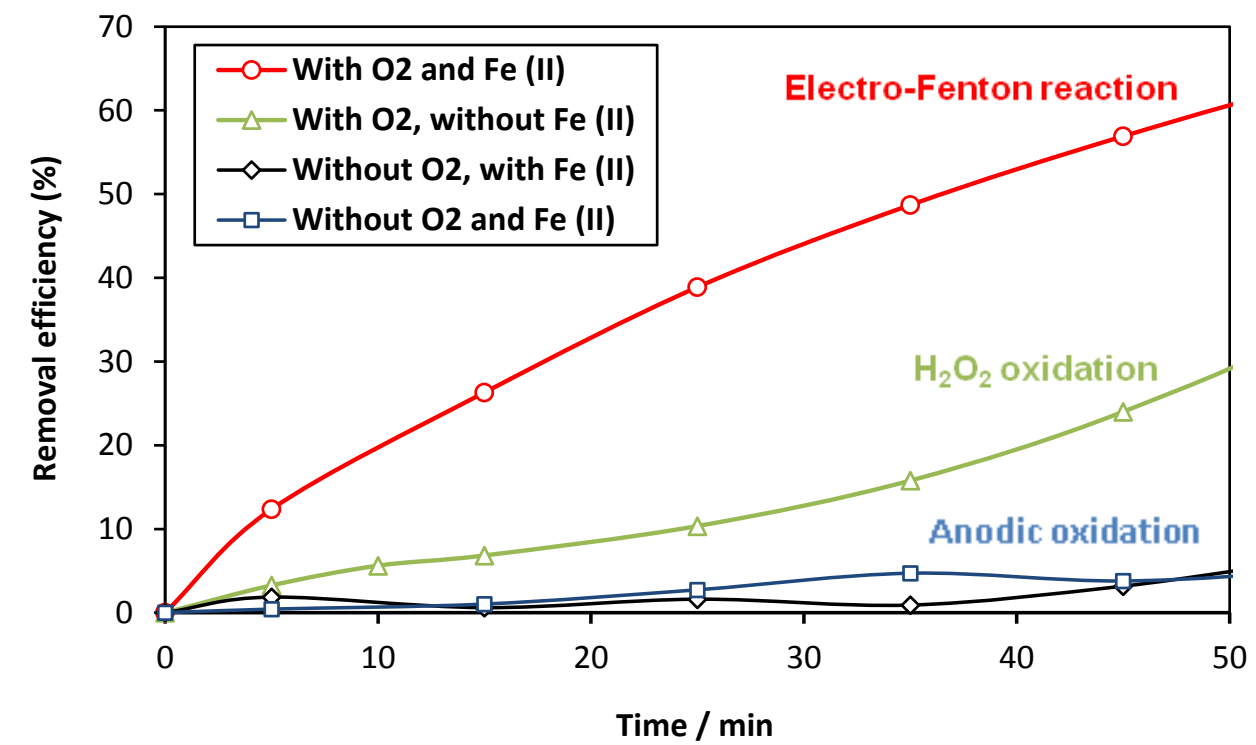

Fig. 6: Evolution of the removal efficiency of BPA by electrolysis in presence/absence of $\mathrm{O}_{2}$ and $\mathrm{Fe}^{\mathrm{II}}$. Experimental conditions: $\mathrm{I}=0.8 \mathrm{~A}$, $[\mathrm{BPA}]=150 \mathrm{mg} . \mathrm{L}^{-1},\left[\mathrm{FeSO}_{4}\right]=0.5 \mathrm{mM},\left[\mathrm{Na}_{2} \mathrm{SO}_{4}\right]=0.05$ $\mathrm{M}, \mathrm{pH}=2.9 \pm 0.1$, Flow rate $=6 \mathrm{~L} \cdot \mathrm{min}^{-1}$ 


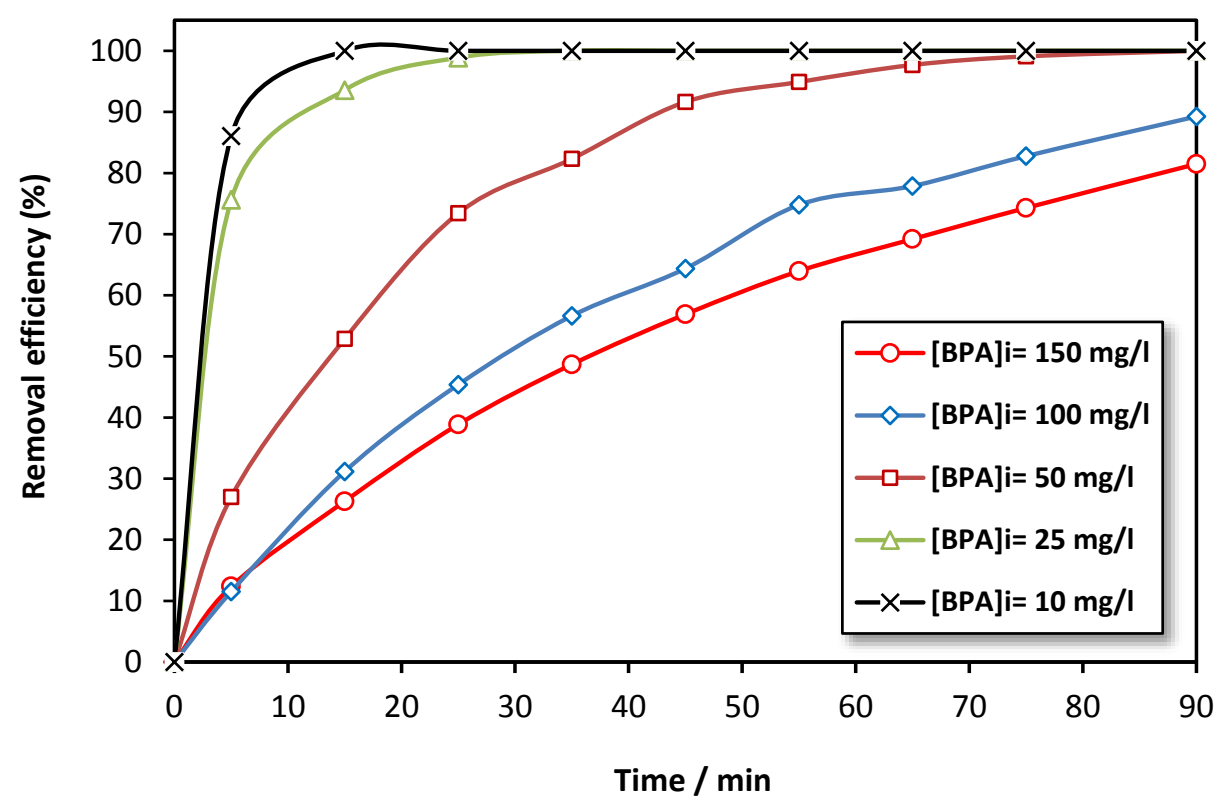

Fig. 7: Effect of the initial concentration of BPA on the degradation kinetics by electro-Fenton process. Experimental conditions: $\mathrm{I}=0.8 \mathrm{~A},\left[\mathrm{FeSO}_{4}\right]=0.5 \mathrm{mM},\left[\mathrm{Na}_{2} \mathrm{SO}_{4}\right]=0.05 \mathrm{M}, \mathrm{pH}=\mathbf{2 . 9} \pm \mathbf{0 . 1}$, Flow rate $=6$ L.min ${ }^{-1}$

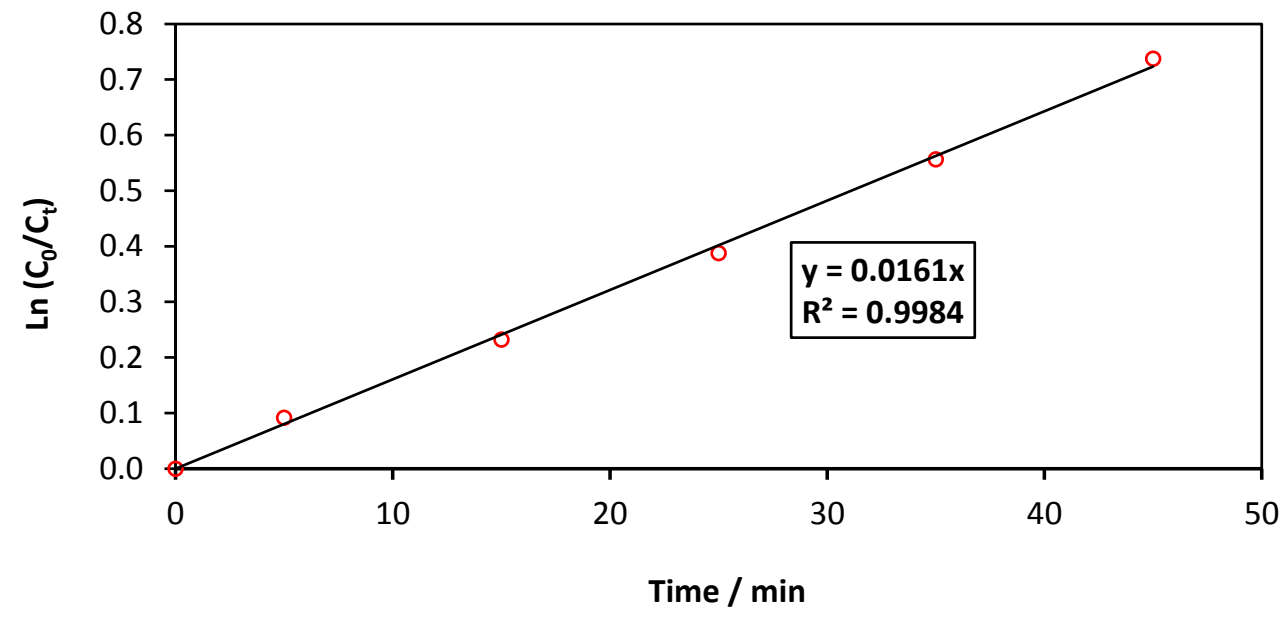

Fig. 8: Variation of $\mathrm{Ln}\left(\mathrm{C}_{0} / \mathrm{C}_{\mathrm{t}}\right)$ functions to time during treatment of BPA by electro-Fenton process. Experimental conditions: $\mathrm{I}=0.8 \mathrm{~A},[\mathrm{BPA}]=150 \mathrm{mg}^{-\mathrm{L}^{-1}},\left[\mathrm{FeSO}_{4}\right]=0.5 \mathrm{mM},\left[\mathrm{Na}_{2} \mathrm{SO}_{4}\right]$ $=0.05 \mathrm{M}, \mathrm{pH}=2.9 \pm 0.1$, Flow rate $=6 \mathrm{~L} \cdot \mathrm{min}^{-1}$ 


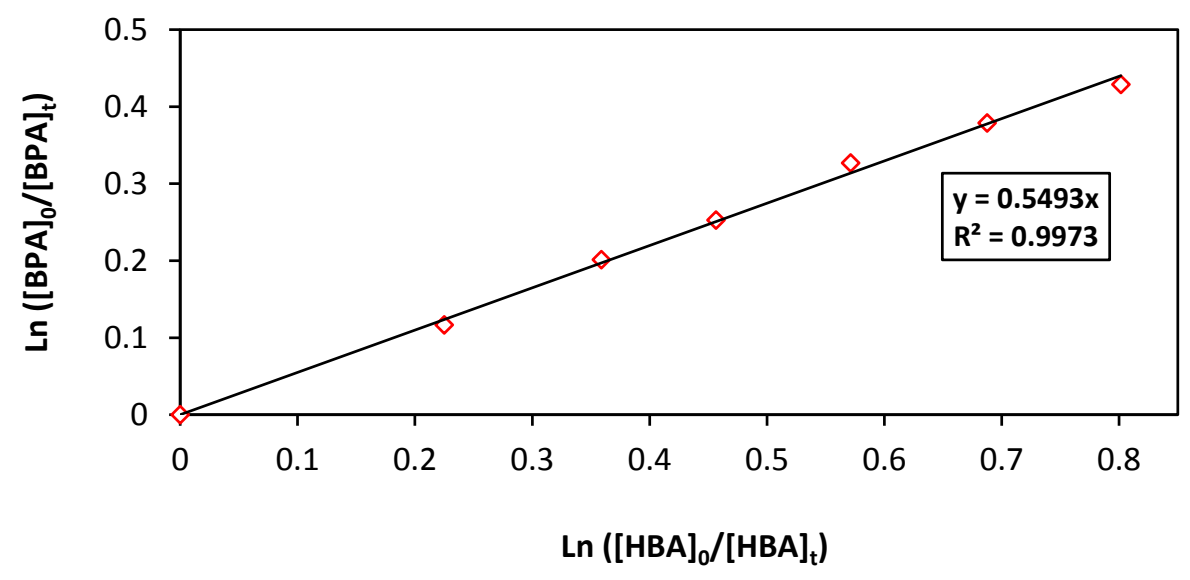

Fig. 9: Competitive method for kinetic analysis of BPA oxidation by the hydroxyl radicals' electro-generated by electro-Fenton process. Experimental conditions: $\mathrm{I}=0.8 \mathrm{~A},[\mathrm{BPA}]=[\mathrm{HBA}]$

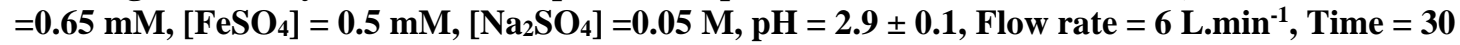
min

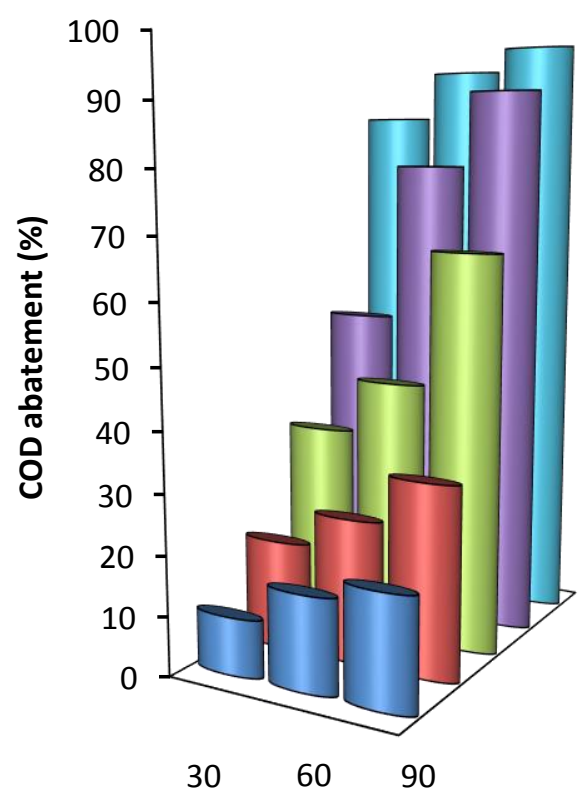

Treatment time / $\mathrm{min}$

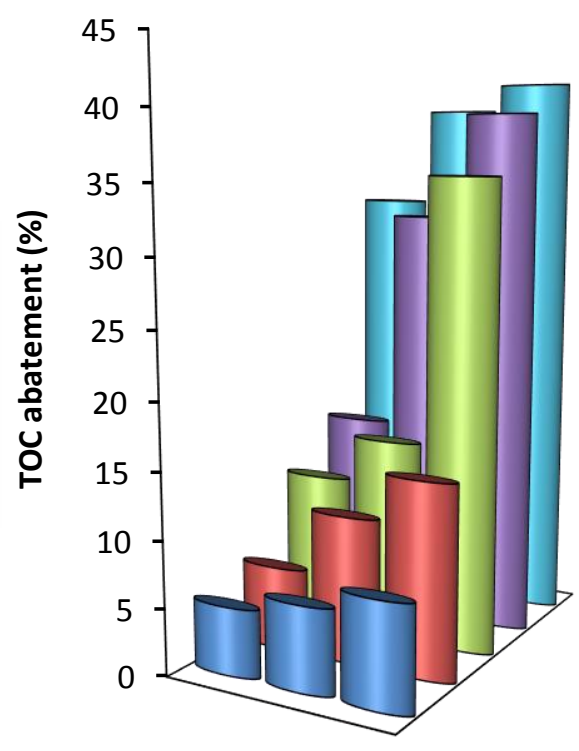

$30 \quad 60 \quad 90$

Treatment time / $\mathrm{min}$

Fig. 10: COD and TOC abatement during treatment of BPA by electro-Fenton process at different time. Experimental conditions: $\mathrm{I}=0.8 \mathrm{~A},\left[\mathrm{FeSO}_{4}\right]=0.5 \mathrm{mM},\left[\mathrm{Na}_{2} \mathrm{SO}_{4}\right]=0.05 \mathrm{M}, \mathrm{pH}=2.9$ \pm 0.1, Flow rate $=6 \mathrm{~L} \cdot \mathrm{min}^{-1}$ 

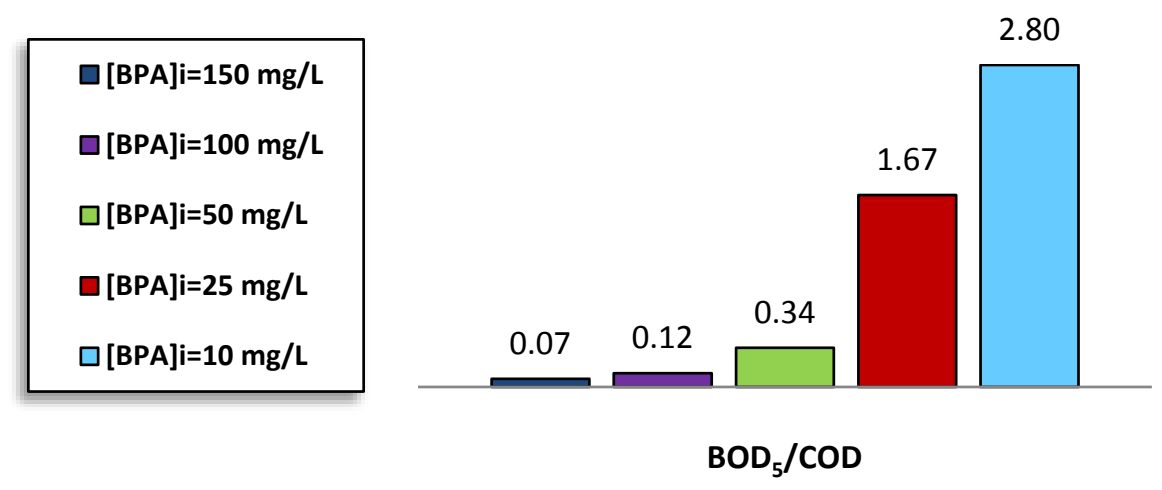

Fig. 11: Variation of BOD5/COD ratio according to the initial concentration of BPA after 90 min of treatment by electro-Fenton process. Experimental conditions: $\mathrm{I}=0.8 \mathrm{~A},\left[\mathrm{FeSO}_{4}\right]=0.5 \mathrm{mM}$, $\left[\mathrm{Na}_{2} \mathrm{SO}_{4}\right]=0.05 \mathrm{M}, \mathrm{pH}=2.9 \pm 0.1$, Flow rate $=6 \mathrm{~L} . \mathrm{min}^{-1}$ 